\title{
The Challenges of Educational Sport in Iran: A Review Study
}

\author{
${ }^{1}$ Mohammadnoor Mohayya ${ }^{(D)},{ }^{1}$ Mohammad Ehsani ${ }^{(D *}{ }^{*}{ }^{1}$ Marjan Saffari $^{(D)},{ }^{1}$ Rasool \\ Norouzi Seyed Hossini \\ ${ }^{1}$ Department of Sport Management, Faculty of Human Sciences and Literature, Tarbiat Modares \\ University, Tehran, Iran.
}

Submitted 09 November 2020; Accepted in final form 12 January 2021.

\begin{abstract}
Background. Educational sport is one of the best tools to fashion motivational forces with respect to sports, which leads to desirable results in sports activities. Today, the path to success in elite and professional sports passes through the attention to educational sports. Objectives. Due to the importance of educational sports, this study aimed to study the challenges of educational sports in the country by reviewing previous studies. Methods. Purposefully and based on the main objective of the research, we investigated papers in the field of educational sports and the findings on problems and limitations in the field along with highlighting keywords comprising educational sports, physical sports, school sports, educational sports challenges, limitations and weaknesses of educational sports, health and physical education in schools from 2011 to 2020 in the country. In this study, related articles were searched by keywords and in specialized databases of Google Scholar, ScienceDirect, PubMed, SID, Magiran, Irandoc. The inclusion criteria for the selected articles were as follows: they need to be in Persian or Iranian articles, be published in prestigious domestic and foreign scientific research journals, and be in the field of educational sports and the examination of harms and weaknesses of it in the country. The results of the searches based on inclusion criteria eventually led to the identification of 26 articles field; by reviewing the articles that were outside the main purpose of this study, they were excluded from the analysis, and finally, 15 completely related and consistent articles were selected. These articles have been in the field of educational sports and their harms and limitations have been reviewed. Results. The findings showed that the weakness and problems involved in the country's educational sports can be of 7 dimensions: lack of sports facilities and equipment, educational weakness, managerial weakness, human resources weakness, lack of financial resources, contextual and individual factors. Conclusion. In developed countries such as China, Japan, the United States, etc. the main basis for the development of sports in the country, as well as the development of elite and professional sports, is physical and educational sports which will necessitate us to get them started from the beginning in schools and universities. Therefore, there should be a fundamental revision of the country's management programs in the field of educational sports in schools and universities.
\end{abstract}

\section{KEYWORDS: Educational Sports, Pathology, Sports Development, Basic Sports.}

\section{INTRODUCTION}

Sport as an all-encompassing social phenomenon is the best implement for providing physical and mental health, therefore, considering it precisely, will reduce costs in health care and anticorruption centers and also lessen the individual and social abnormalities (1). Exercise is very important throughout life and has a great impact on ensuring the physical and mental health of active people. Many of the adverse effects of social, economic, family status, heredity, etc. can be reduced or even eliminated through exercise (2). According to the 1992 Charter of Europe, sport shapes social relations or it is the reason for achieving results at all levels of competition. The development of sports

*. Corresponding Author:

Mohammad Ehsani, Professor

E-mail: ehsani@modares.ac.ir 
in today's world is one of the fruitful ways to achieve lofty goals in various dimensions of development for the governments of developed countries (3). Today, sport and its various dimensions are considered an important issue in different circles and are used as an effective tool and a unique phenomenon to create a dynamic society and overcome many social, cultural, and even economic and political crises (4). Exercise has existed in various forms throughout human life. For example, in ancient times, various sports such as horseback riding, archery, fencing, wrestling, and other sports were common in Iran (5).

Educational Sport .Educational sport as a type of sport that exists accompanying the development of other sports among individuals in terms of quantity and quality by teaching different skills of sports, plays an influential role in the development of psycho-motor skills (6). In general, educational sport means holding educational and developmental classes with regard to one or more sports or skills (7). Considering the importance and functions of educational sports in physical (8), psychological (9), cultural (10) and social (11) dimensions, it is necessary to expand it in any given society. In order to do this, well-built scientific reasons and evidence are needed regarding the functions in various dimensions and areas. This issue has made the need for the role of educational sports in society fully felt (12). Educational sport, however, is not merely responsible for training professional athletes, nor is it responsible for the training of national champions, nor is it responsible for ensuring the health of various segments of society, but it underlies the creation of "proper sports culture", "ethics in sport" and "heroic sports practice". Educational sport is defined within the framework of the strategic planning for the comprehensive system of the physical education and sports' development as follows: "It is a sort of sport through which family and formal educational institutions consciously learn sports skills in certain courses, ended up in highlighting the role and principles of the process with respect to physical and mental health. Educational sports in the context of physical education, like other courses in the country's education programs, and in the Ministry of Education hold a key role in education. As it is defined in the physical education context: Physical education means "education through physical training." This definition signifies a major difference between educational sport and other areas of sport. The difference lies in the word "education." Education, in the sense of transcendence and perfection of human beings, applies only to educational sports and the purpose of education meets only via completing the act of teaching by the very instructor. While in other disciplines, the word coach is used to mean the trainer, who is solely responsible for training athletes physically and mentally and bringing them to their maximum capability. Physical education and sports is a kind of social phenomena that has grown significantly in recent years and also has almost affected individuals purposefully (13)). Sport is one of the most important human activities that has existed in almost every human society. Educational thinkers in earlier times had realized the quality aspects of sport and its enormous power in socializing and normalizing individuals and building a balanced social personality. The connection between sport activities and health has been known for years (14). The most recognized organizations in the country's sport record are student sports and physical education in schools. The management of student sports has been tackling many problems for almost a century since its official beginning, and for this reason, educational sport in the country has not yet been able to provide decent support for public and elite sports (15). Therefore, student sports and physical education of schools need to be rebuilt with respect to the involved management system due to its pivotal role in both the education and the country's sport system. Student sport is an effective approach to increase students' physical activity through sport programs, activities and events in a supportive environment accompanying safe and comfortable infrastructure and facilities (16).

Today, in political forums, in media and the scientific community, and also considering studies in the field of student sports, there is no longer any doubt about the potential of school sports to solve individual's various social, psychological and educational problems (17); so that it can help children to boost their academic progress, health, positive behavior and discipline, as well as the opportunity to socialize and learn new skills. According to the comprehensive system of sport development in the country, sports are separated into educational, public-recreational, athlete and professional aspects. Educational sports or sports of schools and universities are performed by schools, 
educational institutions, and universities, with two sections of physical education and extracurriculars (18). Nasiri Khozani et al. (2020) in a study entitled "Identifying effective factors in the development of student sports participation in Iran" showed that community dynamism, synergy, financing, education, program-based activities, social capital, investment, promotion of participation culture, roleplaying managers, and extracurricular activities in the field of student sports are effective in developing student sports participation in Iran (19).

Due to the importance of educational sports, there are limitations and obstacles with regard to its implementation. Educational sports in the country have faced limitations and problems in various dimensions. These limitations and shortcomings must be scientifically and accurately identified by experts and the relevant planning must be considered precisely to eliminate them. A good body of research has examined the problems and limitations of educational sports and identified barriers from different camera angles. Due to the dispersion in research in the field of educational sports and the fact that there is no comprehensive view of the problems and weaknesses in this area, so the author felt the need to pay attention to this and has tried to provide a comprehensive view of the current state of educational sports in the country through surveying the research background and also investigating the other study findings.

Background Research. In the study of educational sports of the country's comprehensive sports development system, Rahim (2010) based on the SWOT model showed that the WT strategy (within-organization weakness and external threat) is dominant in comprehensive sports plan of educational sports (20). Rasekh et al. (2018) through analyzing the structure of Iranian educational sport system reported that sidestepping bureaucracy, disregarding parallel tasks, level headedly distribution of power, elaborating job nuances and clear communication for all institutions and establishing coordination are the most important principles for coherence and integration of the structure of the educational sport organization in Iran (15).

While analyzing the theoretical foundations of educational sports and extracting effective and influential contextual factors, Naseh et al. (2018) showed political, managerial, planning and policy-making problems, procedures, structure, hardware, and problems in higher education along with perceptual misunderstandings, impinge on educational sports and physical education in schools (21). Rastogi and Sharma (2017) examined the status of physical education development in schools of different countries and stated that although there are appropriate methods and programs for the development of school sports in most countries, but still a coherent and integrated program for the development of sports in schools is required. To put it differently, there is a lot of evidence regarding the failure of sports development programs in schools (22).

Samiei et al. (2016) in a study entitled "analysis of managerial and structural changes in physical education and student sports" showed that managerial adjustments in school physical education and student sports did not follow a sustainable policy and was more a function of structural alterations in education; therefore, it is necessary to review the division of labor between departments, and the participation of stakeholders and those in charge of student sports. (23). Zolghadri et al. (2018) in their survey entitled "pathology of physical education and health curriculum implementation in the first year of high school within their given framework", they concluded that the problems of physical education and health curriculum implementation span a wide range of curriculum components encompassing educational space, time, content, objectives, teacher role, materials and resources. Accordingly, it is suggested that policymakers and administrators in the physical education curriculum align the elements with the objectives, improve the learning environment, and fine-tune the teaching time to address the identified weaknesses (24).

In their study entitled "explaining the factors affecting the success of the intramural sports Olympiad", Saatchian et.al. (2018) showed that six factors: cultural, financial, human, material and facility, management and technology resources affect the success of the Olympiad Sports within schools (25); Therefore, it is suggested that in order to better plan the intramural sports olympiad, special attention should be paid to the identified resources in order to increase various aspects of students' health and improve useful social relationships along with their good spirit. Educational sport occupies a special place in the formal education system (from preschool to university) and is considered firmly within the country's macro- 
policies (26). The development of physical education and sports as a basis for providing and training healthy manpower is part of national development programs and has been considered in the national vision of the Islamic Republic of Iran' outlook in 1404 and the connected macro-policies in the five-year development plans of the country. Also, in the upstream documents of the Ministry of Education, both in the document of fundamental change in education and in the national curriculum, physical education has been considered sharply along with religious, intellectual, and emotional-social education.

Educational Sports in Schools and Educational Environments. Physical activities and sports in schools span from basic and simple actions to games and elite sports, so it should be very diverse in all academic courses to meet the physical, psychological, emotional and social needs of students. This position has placed a heavy burden on the physical education and sport sections of schools (27). The model which Mul et al. (2005) proposed is one of the wellknown approaches with regard to the hierarchical aspects of sport which is divided into four levels of educational sports, public and recreational sports, elite sports and professional sports. At the base of the pyramid is the educational sport, topped by professional sports at the apex of the pyramid (28). The highest level of participation is at the base of the pyramid, and the number of participants in the sport decreases as we approach the top of the pyramid. According to this, sports skills, strategies, and other requirements are taught in the standard courses of schools and universities. Shibouri et al. (2008) have also divided sports into these four levels in which educational and introductory sports are at the base of the pyramid, and at the next level are public and heroic sports, followed by professional sports at the top of the pyramid (29). Therefore, physical education and sports are an integral part of education, especially in adolescence and youth, not only as an input in an educational system, but also as one of the important factors in the operational process in improving the quantitative and qualitative level of the output of any educational institution. As so, it is a must for developed countries to have comprehensive plans in order to achieve the goals of education and physical training (30).

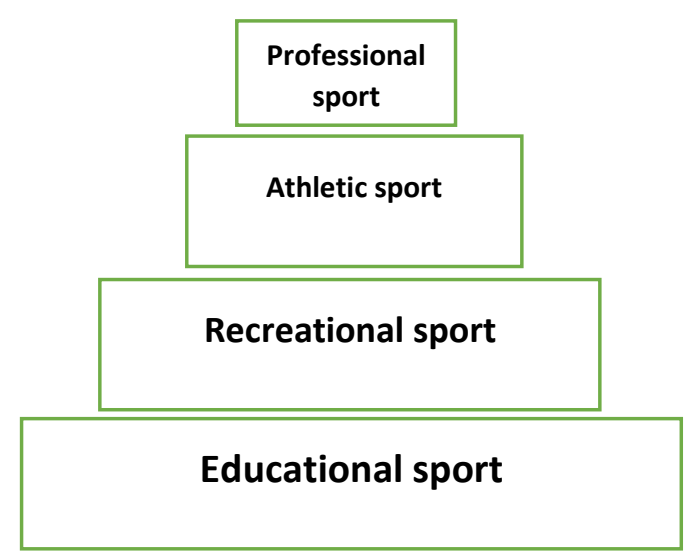

Figure 1. Pyramidal Model of Levels of Sports

Programs in Society Based on Mull Model (2005)

Sport management community should concentrate most of its efforts on educational sports. More importantly, basic sports are the path to elite and professional sports. The educational aspect of sport is mainly common in academic and institutional organizations. Therefore, it is necessary to provide opportunities, experiences of motor and skill training and a wide range of possibilities to strengthen the basic foundations of the next and higher level of the sport. Educational sport in schools is of three levels. Any country needs to develop and expand its sport structure by maintaining balance at these levels and prioritizing these dimensions based on its related application and position (31).

As shown in the chart below, the basis of physical education and sports in schools is the emphasis on physical activity of children and, upholding the health and vitality of children is a priority in school sports programs and activities. T. Sangarido (2017) in a study examined the views and understandings of primary school teachers toward the main challenges of physical education in Cypriot schools. He stated that participants believe that the main goal of physical education in the early years should be to create opportunities for children to reinforce psychological and cognitive development, and also their social skills. The physical education should be an important issue in the school curriculum (32); therefore, paying attention to sport activities in which there is any kind of competition residing at the next level and priority; so that children should first be taught the benefits of exercise and physical activity, and if this goal is achieved, then we can go to the next level where competitive and elite sports come to play. Hence, according to what we said, the importance of 
educational sports is quite clear, which then should be a priority regarding the planning for sports and educational managers. A good many studies have shown that there are limitations and problems with respect to the field of educational sports in the country. In the present study, the researcher brought all these investigations together and proposed an over-all and inclusive view concerning the very aspects of the educational sport. Therefore, the purpose of this study is to summarize and provide a comprehensive view of the problems in the field of educational sports in the country. And also, we are in the bid of striving to seek answers to what are the different dimensions of educational sport disadvantage in the country?

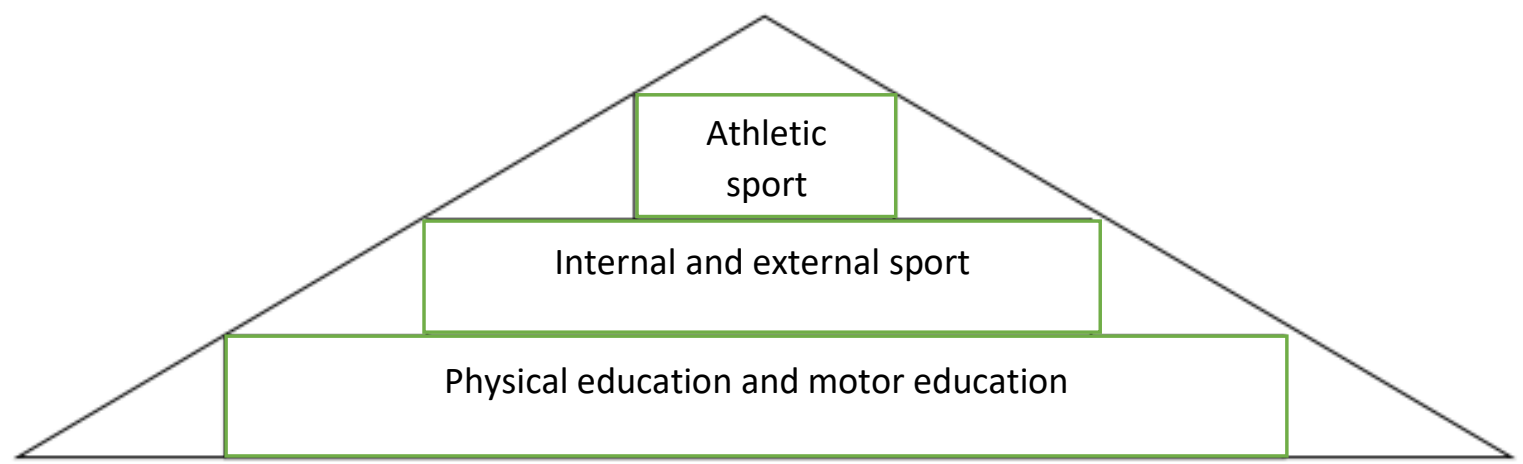

Figure 2. Sport Levels in Schools (Shilbury et al., 2008)
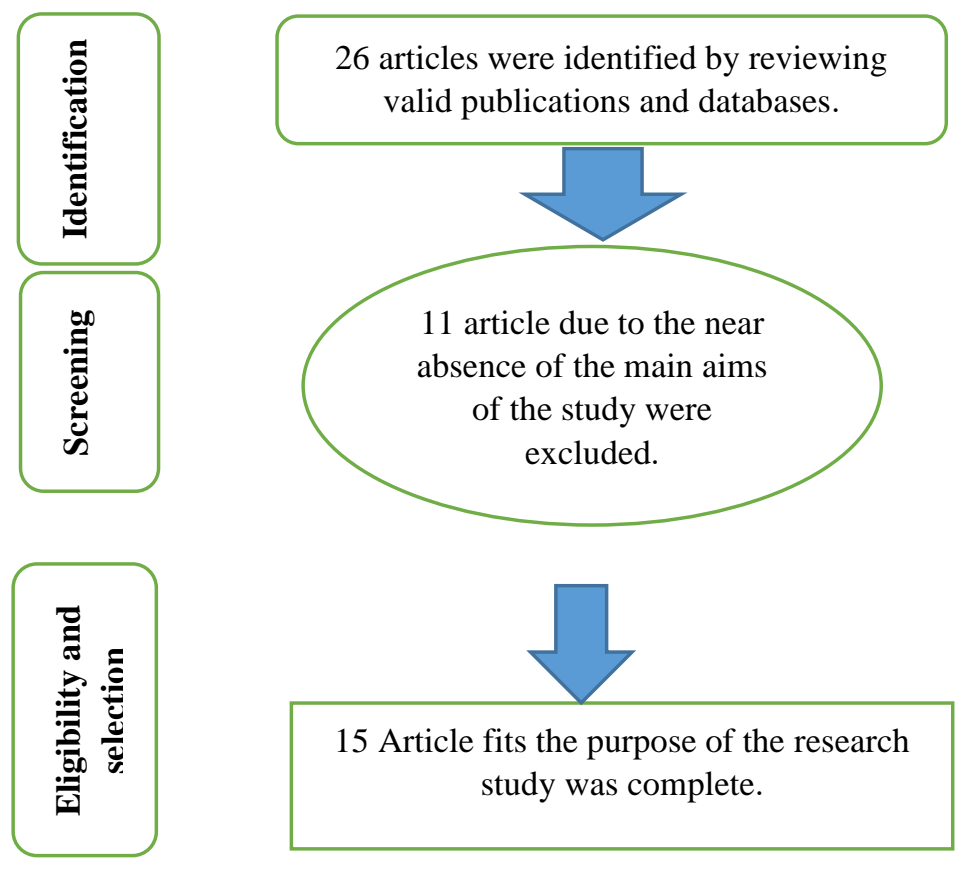

Figure 3. Flowchart of the Stages of Entering Studies into the Research

\section{MATERIALS AND METHODS}

We descriptively review the available resources through libraries and probing within internal article databases. In the current study, purposefully and based on the main objective of the research, we investigated papers in the field of educational sports and the findings on problems and limitations in the field along with highlighting keywords comprising educational sports, physical sports, school sports, educational sport problems, limitations and weaknesses of educational sports, health and physical education in schools from 2011 to 2020 in the country. In this study, keyword related articles were searched in given databases such as Google Scholar, ScienceDirect, PubMed, SID, Magiran, and 
Irandoc. The inclusion criteria for the selected papers were as follows:

Be in Persian or Iranian article.

Be published in prestigious domestic and foreign scientific research journals

$\mathrm{Be}$ in the field of educational sports and also be related to problems and weaknesses of this field in the country.

The results of the searches based on the inclusion criteria finally led to the identification of 26 articles in the field under study; By reviewing the articles that were outside the main purpose of this study, they were excluded from the analysis and, finally 15 completely relevant and consistent articles were selected. Also, no article related to the purpose of the research and published in non-Iranian journals was found.

\section{RESULTS}

From 26 selected Iranian articles, 15 papers were finalized using the inclusion and exclusion criteria (being relevant in the field of examining the problems and weaknesses of the country's educational sports). The final output of the selected articles is presented in Table 1. Table 1 shows the details of the mentioned studies, including the name of the author, the year of publication, the components related to the problems and weaknesses, and the limitations of the country's educational sport. The next stage was the extraction of sub-themes and main themes. In this stage, according to the results, subthemes were extracted and presented in Table 1. According to the codes extracted from the subthemes, the researcher classified the codes that were conceptually close to each other in 7 categories and the main themes which include 1) lack of facilities and sports equipment, 2) educational weakness, 3) managerial weakness, 4) human resources weaknesses, 5) lack of financial resources, 6) underlying factors, 7) individual factors, were considered as problems of educational sport in the country.

\section{DISCUSSION AND CONCLUSION}

The results of this study showed that problems in the field of educational sport in the country are of 7 dimensions: lack of sports facilities and equipment, educational weakness, managerial weakness, human resources weakness, lack of financial resources, underlying factors, and individual factors. Research results of Zolghadri et al. (2018), Samiei et al. (2019), Naseh et al. (2018), Rahim (2010), Vafaee Moghadam et al. (2018), Pilhavar Mokher et al., Vahdani (2016), Mustashiri et al. (2017), Ghanbari et al. (2017), Mohammadi (1390), Soltani Moghadam (1393), Hashemi (1393), Valadi and Hamidi (1399), Malihi et al. (1397), Saadatmand et al. (2012), Jahandideh and Lotfi (2016), Shahbazi et al. (2013) and Ghanbari Firoozabadi et al. (2016) showed that the educational sport in the country has shortcomings, limitations and problems, requiring proper plans and immediate actions (20, 21, 23, 24, 33-47).

Lack of Sport Facilities and Equipment. The results disclosed that the lack of sport facilities and equipment comprises the very components as the lack of sports space, the lack of hardware and software facilities, the lack of sport equipment and the lack of adequate sport infrastructure in the countries educational sport facilities. The appropriate sport facilities and infrastructure in educational environments could be considered as a basis for the development of educational sports in the country, so suitable investment should be made to develop appropriate sport facilities and updates in educational environments, including schools. In order for developed countries to be successful in the field of sports, it is needed to have up-to-date and equipped sport complexes for the development of educational sports. The hardware dimension includes items such as sports facilities and equipment that provide the basis for sports activities in educational settings such as schools. Hardware refers to sports facilities and equipment that provide the basis for sports activities in educational settings such as schools. Physical education is one of the courses that is highly dependent on educational facilities and equipment. With the help of educational tools and facilities, the teacher can explain the most content to the students in a more realistic and tangible way in the shortest time. In choosing educational materials and resources, one should pay attention to individual characteristics, level of knowledge and needs of learners, students' interests, attractiveness and validity of learning materials, and resources (24). Therefore, it can be said that the existence of appropriate hardware facilities and equipment is one of the priorities of sports education and physical education lessons in educational environments. 
Table 1. The Final Output of the Selected Articles

\begin{tabular}{|c|c|c|c|}
\hline No & Author & Output & Sub-Themes \\
\hline 1 & $\begin{array}{l}\text { Zolghadri et.al. } \\
\qquad(2018)\end{array}$ & $\begin{array}{l}\text { Problems of physical education and health curriculum implementation } \\
\text { include a variety of curriculum components such as educational space, } \\
\text { time, content, objectives, teacher's role, materials and resources. }\end{array}$ & $\begin{array}{l}\text { Lack of sports space (1), lack of time (3), poor } \\
\text { course content (2), weak objectives (2), the poor } \\
\text { performance of teacher (4), lack of facilities (1) }\end{array}$ \\
\hline 2 & $\begin{array}{l}\text { Samiei et al. } \\
\qquad(2019)\end{array}$ & $\begin{array}{l}\text { Managerial changes in school physical education and student sports have } \\
\text { not followed a sustainable policy and are more a function of structural } \\
\text { changes in education. }\end{array}$ & managerial weakness (3) \\
\hline 3 & $\begin{array}{l}\text { Naseh et al. } \\
\qquad(2018)\end{array}$ & $\begin{array}{c}\text { Management, planning and policy-making problems, procedures, } \\
\text { structures, and problems in higher education, along with perceptual } \\
\text { misunderstandings, affect educational sports and physical education in } \\
\text { schools. }\end{array}$ & $\begin{array}{l}\text { Managerial weakness (3), planning weakness } \\
\text { (3), lack of hardware and software facilities (1) }\end{array}$ \\
\hline 4 & Rhahim (2010) & $\begin{array}{l}\text { The results showed that the WT strategy in educational sports is the } \\
\text { dominant sports plan of the country. }\end{array}$ & - \\
\hline 5 & $\begin{array}{l}\text { Vafaee } \\
\text { Moghadam et } \\
\text { al. }(2018)\end{array}$ & $\begin{array}{l}\text { Findings showed that in the internal environment of the organization, the } \\
\text { managerial, human, financial, facilities and infrastructure dimensions and } \\
\text { the structure of the education system are among the priority obstacles } \\
\text { affecting the development of primary school sports. Otherwise, cultural } \\
\text { environment weakness, lack of use of technology, unhealthy social } \\
\text { environment, lack of laws and recession in the economic environment are }\end{array}$ & $\begin{array}{c}\text { Managerial weakness (3), human resource } \\
\text { weakness (4), lack of financial resources (5), } \\
\text { lack of facilities and infrastructure (1), cultural } \\
\text { weakness (6), lack of use of technology (2), } \\
\text { economic weakness (5) }\end{array}$ \\
\hline
\end{tabular}
sports.

$\begin{array}{cccc}\text { 6 } & \begin{array}{c}\text { Pilhavar } \\ \text { Mokher et al. } \\ \text { (2016) }\end{array} & \begin{array}{c}\text { Insufficient budget for sports and the transfer of these funds to other } \\ \text { school expenses was an internal challenge for student sports in Khorasan } \\ \text { Razavi province. The emergence of structural abnormalities among } \\ \text { students due to lack of sports activities was the external challenge of } \\ \text { student sports. }\end{array} & \text { No allocation of specific budget (5) } \\ \begin{array}{c}\text { Abdi } \\ \text { Moghadam } \\ \text { et.al (2018) }\end{array} & \begin{array}{c}\text { The results showed that there is a significant difference between the } \\ \text { position of physical education course and in comparison to other courses } \\ \text { in terms of students, parents, principals and teachers; the physical }\end{array} & \begin{array}{c}\text { Parents' perceptions of physical education } \\ \text { lessons (6) }\end{array}\end{array}$

education course is not among the 5 important courses therein.

$8 \quad$ Mustashiri et Findings showed that the lack of appropriate classes and sports facilities, al. (2017) insufficient perception of the impact of exercise on health and rejuvenation were the most important barriers to students' participation in

Lack of sports facilities (1), Lack of sufficient knowledge on the positive effects of sports (6) physical activities in schools.

9 Ghanbari et al. According to the findings, organizational, individual and contextual

\begin{tabular}{|c|c|c|c|}
\hline 10 & $\begin{array}{l}\text { Mohammadi } \\
\text { (1390) }\end{array}$ & $\begin{array}{l}\text { Limitations and barriers to high school students' participation in sports } \\
\text { activities were lack of space and necessary facilities, lack of attention of } \\
\text { officials, inappropriate time for sports activities, fear of academic failure, } \\
\text { lack of assignment of coaches to sports venues, lack of sufficient } \\
\text { information about sports and lack of interest. }\end{array}$ & $\begin{array}{c}\text { Lack of sports facilities (1), lack of attention of } \\
\text { officials (3), lack of coaches with specialized } \\
\text { education (4), }\end{array}$ \\
\hline 11 & $\begin{array}{l}\text { Soltani } \\
\text { Moghadam } \\
\text { (1393) }\end{array}$ & $\begin{array}{l}\text { Lack of adequate sport equipment and space, lack of supervision of } \\
\text { physical education officials and the parents and teachers Association in } \\
\text { advancing the objectives of the lesson were obstacles to the } \\
\text { implementation of physical education in schools in South Khorasan } \\
\text { province. }\end{array}$ & $\begin{array}{l}\text { Lack of adequate sports equipment (1), Lack of } \\
\text { supervision of sports officials (6), }\end{array}$ \\
\hline 12 & $\begin{array}{l}\text { Hashemi } \\
\text { (1393) }\end{array}$ & $\begin{array}{l}\text { The results showed that barriers such as cultural, financial, structural, } \\
\text { time-dependent, motivational, physical-psychological, managerial and } \\
\text { planning have affected the growth and development of basic school } \\
\text { sports. It is suggested that each of the barriers should be examined } \\
\text { separately by teachers and experts and that effective measures and } \\
\text { solutions be provided to increase the progress of basic sports. }\end{array}$ & $\begin{array}{c}\text { Cultural Barriers (6), Financial Barriers (5), } \\
\text { Time Barriers (3), Motivational Barriers (7), } \\
\text { Physical-Psychological Barriers (7), } \\
\text { Management and Planning Barriers (3) }\end{array}$ \\
\hline 13 & $\begin{array}{l}\text { Malihi et al. } \\
\text { (2018) }\end{array}$ & $\begin{array}{l}\text { Findings showed that in the content of preschool books, it has not been } \\
\text { paid any attention to the word physical activity, the importance of } \\
\text { physical activity and the concept of rhythmic movements. }\end{array}$ & $\begin{array}{l}\text { The less-insignificancy of physical education in } \\
\text { course books (2), }\end{array}$ \\
\hline 14 & $\begin{array}{l}\text { Jahandideh and } \\
\text { Lotfi (2016) }\end{array}$ & $\begin{array}{l}\text { One of the current problems of teaching physical education in the } \\
\text { country's schools is the lack of a common view among the teachers of } \\
\text { this subject and also the lack of sufficient knowledge about the } \\
\text { objectives, which has led to many problems in this field. }\end{array}$ & $\begin{array}{l}\text { Less teaching literacy (4), lack of common } \\
\text { understanding of the goals of physical education } \\
\text { (2) }\end{array}$ \\
\hline 15 & $\begin{array}{c}\text { Valadi and } \\
\text { Hamidi (2019) }\end{array}$ & $\begin{array}{l}\text { The study showed that students aged eight to twelve do not have an } \\
\text { acceptable level of physical literacy. This indicates that second to sixth- } \\
\text { grade students are far from having an active and healthy lifestyle, and if } \\
\text { this issue is not taken seriously, the health of this segment of society may } \\
\text { face different physical, mental and motor risks in the future. }\end{array}$ & $\begin{array}{c}\text { Low level of physical literacy for students aged } \\
\text { eight to twelve (2) }\end{array}$ \\
\hline
\end{tabular}
(2017) factors had the most effect in the field of physical education and school sports, respectively. Among the sub-themes of all three levels, the physical education teacher (organizational level) confronted the most problems and the environment (background level) faced the least difficulties. Organizational level problems have had the greatest impact on the development of physical education and school sports.

Therefore, it is necessary to review the planning of the Ministry of Education, allocating resources and equipping schools in this regard. At the individual level, educating families and at the level of the underlying factor, promoting a culture of sports orientation and promoting public sports are considered necessary and useful measures.

Insufficient media support, especially the national media, with respect to physical education and student sports (6), lack of attention by many municipalities to the condition of parks and sports venues around schools (6), the negative view among some members of society that sport causes physical problems (6), low intrinsic interest of some children in physical activity (7), insufficient allocation of families for physical activities (7)

Lack of sports facilities (1), lack of attention of co coaches with specialized education (4),

cials, inappropriate time for sports activities, fear of academic failure, po coaches to sports venues, lack of sufficient Lack of adequate sport equipment and space, lack of supervision of advancing the objectives of the lesson were obstacles to the education in schools in South Khorasan The results showed that barriers such as cultural, financial, structural, -dependent, motivational, physical-psychological, managerial and lanning have affected the growth and development of basic schoo (1) suggested that each of the barriers should be examined indings showed that in the content of preschool books, it has not been d any attention to the word physical activity, the importance of physical activity and the concept of rhythmic movements.

One of the current problems of teaching physical education in the try's schools is the lack of a common view among the teachers objectives, which has led to many problems in this field. study showed that students aged eight to twelve do not have an grade students are far from having an active and healthy lifestyle, and if face different physical, mental and motor risks in the future. 
Educational Weakness. The results showed that the weakness of education includes poor content, lack of technology, lack of physical education concepts in books, lack of common understanding of the goals of physical education, low physical literacy of students aged eight to twelve. Highlighting the significance of sports and physical activity and the related benefits is one of the most central factors that should be considered in textbooks and educational environments; the available resources in the field of educational sports should be recruited properly and the axis of education should be laid on modern science consideration therein. The practical nature of the physical education course requires more extensive student activity than other courses. Therefore, the selected learning activities should be adapted to the needs, interests, information, and current experiences of students and provide them with the opportunity to practice physical education lessons. Also, in choosing learning activities, their cognitive, physical, and emotional readiness should be given enough attention. Therefore, it can be said that the educational components in the educational sports sector should be in line with the goals set for this sector, and in the educational sector, specialized and experienced human resources should be used in educating children and adolescents in educational environments.

Managerial Weakness. The findings imply that the problems regarding management include the of lack of time, the lack of planning, the lack of attention of officials. The management of any organization or institution is the most important part of the decision making and planning process. If this sector does not perform properly in performing its duties, development and success cannot be achieved accurately. In educational sports, the management department must be careful in planning and making the decision and should act in accordance with the objectives and perspectives of the development of educational sports in the country. The Ministry of Sports and Youth, the Ministry of Education, the Ministry of Science, the sports federations and all the bodies involved in this field must coordinate and cooperate jointly for the development of educational sports. Volti and Cohen (2016) in a study showed that the success of school sports management depends on planning, communication, division of labor, importance to stakeholders, coordination, monitoring, and evaluation respectively. In fact, management in educational sports is the most important part that can affect the success or failure of educational sports development. In the field of educational sports, people who have both a good sports background and education related to sports and management should be used (48).

Human Resources Weakness. Based on results, this dimension includes low teacher job commitment, lack of human resources, lack of specialized trainers and scientific weakness of sport teachers. Human resources problem plays a very chief role in sports education in the country. Highly erudite as well as educated and wellinformed sport instructors should be hired in sports education settings. In developing countries, coaches with high expertise and more knowledge in the field of educational sports and basic sports are employed. Hence, the most important issue in human resources is the use of experts in educational sports. In Razavi et al.'s (2011) study, low salaries and benefits of teachers and their tendency to non-sports jobs to earn more income, low teaching motivation in physical education teachers, reforming the structure and organization of physical education are among the components that have been expressed as effective factors in the quality and optimal performance of physical education courses in schools (49). Therefore, paying attention to the basic needs of sports teachers and coaches who strive for the development of sports in educational fields is one of the most important points that should be considered and planned for.

Lack of Financial Resources. This dimension embraces economic shortcoming, lack of allocation of specific funds, and financial barriers. The success and development of all sectors, including the educational sector, can be achieved if a special budget is considered for different sectors of sport in the country. There is no special budget for educational sports such as elite and professions sports because the importance of this sector has not been realized in our country. Therefore, the senior managers of the country's sport sector should be alert that if they are looking for further development of even elite and professional sports, they should first invest in educational sports. It can be said that the main reason that our country does not have suitable conditions for special disciplines such as athletics, swimming and gymnastics at the international level is the lack of serious attention and lack of investment in educational sports. 
Underlying Factors. The results showed that the underlying factors encompass cultural weakness and the view of parents toward physical education lessons, insufficient media support, especially the national media, for physical education and student sports, lack of attention to the condition of parks and sports venues around schools by many municipalities, and the negative view among some members of the community that exercise causes physical harm. In addition to the support of administrators and officials for educational sports, there should be a general tendency among people and families to encourage children to consider sports seriously, and the concept of sport should be institutionalized in society. The role of the media in the development of educational sports is of great importance, the media should pave the way for the development of sports and the implementation of various programs. In the field of educational sports, the media can also help the development of the very sport by producing and then broadcasting television programs.

Individual Factors. This dimension includes motivational barriers, physical-psychological barriers, low intrinsic interest of some children in physical activity, and less time spending of families on physical activities. Obviously, we can see the development of educational sports if the conditions seem to be appropriate for exercising and teaching sports in educational environments such as schools. There should be enough sport space for all people with different physical and mental conditions. In addition to people who are physically healthy and can do various kinds of sports, people who are not in perfect physical health should also have an environment to exercise, though. Therefore, one of the most important issues in this area is to pay close attention to people with special physical conditions, which should also provide the necessary background and related facilities for them so that they, too, can enjoy the benefits of sports and develop their talents. One of the consequences of machine life and technological progress in the present century is poor mobility and reduced physical activity in people. Promoting physical activity is one of the most important and effective strategies to reduce the risk of some non-communicable and chronic diseases such as cardiovascular disease, diabetes, osteoporosis, obesity, and some types of cancer (21). Due to the increase in various diseases that occur as a result of inactivity, attention should be paid to exercise and physical activity from childhood. Encouraging people to exercise and physical activity and increasing their awareness of the benefits of sports is one of the most important issues in the development of sports culture in society. If we try to institutionalize this culture in people from school and childhood, the results will surely be much better.

Educational sport seeks to provide the necessary conditions and creates a suitable environment and opportunity, to put all learners in healthy educational situations and by responding to their basic needs, tries to strengthen the body, in line with the principles and steps to bring growth and harmony correspondingly. The educational sport needs the largest and most efficient organizational structure to provide the most basic experiences in a community through specialized, committed and efficient forces. Achieving a comprehensively balanced physical, skilled, cognitive, emotional and social education is among the central goals of the country's sport organizations in schools and universities. This level requires extensive facilities and equipment to be able to trigger a positive attitude towards sports and physical activities in children and adolescents during the period of education; therefore, one of the dominant missions of any government is to prepare the ground for sports at the level of schools and universities. According to Theodore and Claudio (2013), educational sport is one of the best ways to create a motivational force for exercise in individuals that leads to desirable results in sports activities (50). Also, today, the path to success in elite and professional sports passes through attention to educational sports. Countries that put special attention on and invest in student sport achieve greater success at the level of elite and professional sports. For example, the system for discovering sports talent in China is based on the interaction of provincial sports with the education system. Many young sports talents in Canada are also identified through school competitions (51). In Japan, physical education departments play a major role in the development of sport at the public level. The importance of paying attention to sports at the level of education has clearly seen in today's developed countries. To have a prosperous future in elite and professional sports, they start the process of identifying top sports talents from schools and universities, and by investing 
properly in the identified talents, they guarantee the future of their country's sports. There are problems involved in the process of managing educational sports in schools and universities, as well as infrastructure problems and limitations in the field. The necessary facilities and equipment must be provided for the upbringing of children and training adolescents in schools and educational settings.

Conclusion. The main purpose of this study was to review and summarize the researches that were done in the field of educational sports and the problems in it; According to the summary of the researches, it can be said that better and more appropriate plans should be designed to improve the situation of educational and training sports in the country. Educational sports should be considered the most basic dimension of sports in society. We also need to reconsider the way we look at educational sports from managerial, economic, infrastructural, social, and cultural dimensions and try to create a more appropriate and better view of this issue in society.

Limitations. The results of this study were a summary of the previous studies, so understanding the accuracy of the results of previous studies was one of the main limitations of this study, and the researcher only cited the results based on the fact that the research was published in a reputable journal. In this research, Iranian research has been used. In order to better understand the position of educational sports in different societies, researchers who are interested in research in the field of educational sports are suggested to use a combination of internal and external research in future research to gain a more accurate insight into educational sports in the world. It is also suggested that in future research, in-depth interviews be conducted with the directors and officials of educational sports in the country in order to identify the challenges and harms in this field more accurately.

Active institutions in educational sports in our country are the Ministry of Youth and Sports, National Olympic Committee, Sport Clubs, Ministry of Education, Student Sports Federation, Ministry of Science, Research and Technology, National Federation of University Sports, the Ministry of Health, the Islamic Azad University and also the General Staff of the Armed Forces, so it can be said that all-important institutions in the country are simultaneously involved in the development of educational sports; each of which plays its role in the development of educational sports in the country. Therefore, the main point for the country's sports managers to be mentioned here is to pay special attention to educational sports as the foundation of sports in the country and as a basis for the development of sports at the community level.

\section{APPLICABLE REMARKS}

- It is suggested that Iran should have a say in sports like gymnastics, athletics, and swimming at the world level. This could be achieved when any involved organization pays special attention to sports. According to the results of this study, suggestions are made to pay more consideration to education and training, as well as to advance the situation in the country.

- Due to the educational weakness dimension, it is recommended to use the word physical activity used in the content of preschool and primary school textbooks.

- Concerning the lack of sports facilities and equipment, it is suggested that the country's schools be equipped with appropriate and quality sports facilities and equipment under sports and educational goals in different educational courses.

- According to the educational weakness dimension, it is suggested to look at physical education and sports activities as an important course and also as a factor for the development and reduction of physical and mental illnesses in society.

- Due to the lack of human resources, it is proposed that physical education graduates and coaches be employed to educate children in schools and colleges.

- Owing to managerial weakness, it is suggested the scientific approaches, goals, and strategies in the field of physical education be determined and the priorities are evaluated by senior physical education directors.

- Due to the lack of financial resources, it is recommended to prevent the uncontrolled expansion of school sports, especially those not applicable in schools or unsafe concerning students' health.

- Based on the individual factors, it is advised that special sports facilities and equipment be provided for people with special physical conditions. They are treated like healthy people so that they also have the right to exercise and receive training. 


\section{REFRENCES}

1. Baker C, El Ansari W, Crone D. Partnership working in sport and physical activity promotion: An assessment of processes and outcomes in community sports networks. Pub Polic Admin. 2017;32(2):87109. doi: $10.1177 / 0952076715625104$

2. Mohammadi Bradbury M, Baba Ahmadi G, Bani Sertangi B, Baba Ahmadi V. The physical, psychological and social benefits of exercise on children. First National Conference on Social Sciences, Education, Psychology and Social Security, Tehran.2017.

3. Jenkinson KA, Benson AC. Physical education, sport education and physical activity policies: Teacher knowledge and implementation in their Victorian state secondary school. Europe Physic Educat Rev. 2009;15(3):365-388. doi: 10.1177/1356336X09364456

4. Salimi M. Providing a model of professional ethics development in sports organizations. J Ethic Sci Technol Twelfth. 2017;1:1-13. doi: 10.1007/978-3-319-23514-1_180-1

5. Rouhi M. Physical Education in Educational System of the Ancient Iran. J America Sci. 2012;8(3):276280.

6. Zeigler EF. Socio-cultural foundations of physical education \& educational sport (Vol. 2). The Western University of London Ontario.2003.

7. Mottaghi Shahri MH, Ghafouri F, Honari H, Shahlaee Bagheri J. Designing the Subjective Well-being Pattern of Athletes Participating in Educational Sport. Res Educat Sport. 2019;7(16):17-38. doi: 10.22089/RES.2018.5430.1417

8. Paes VR, Amaral SCF. Public policies for educational sport in São Paulo: Impacts of the 2016 Olympic Games. Movimento. 2017;23(2):715-728. doi: 10.22456/1982-8918.71006

9. Lopiano DA. It's time for the NCAA and other educational sport governance organizations to get serious about gender equity. $J$ Physic Educat Recreat Dance. 2014;85(2):6-7. doi: 10.1080/07303084.2014.866784

10. Reis NS, Santos SA, Carneiro FHS, Matias WB, Athayde PFA, Mascarenhas F. The educational sport as the theme of knowledge production in the Brazilian scientific journalism: A systematic review. Pensar a Prática. 2015;18(3):12-20. doi: 10.5216/rpp.v18i3.34326

11. Hills AP, Dengel DR, Lubans DR. Supporting public health priorities: recommendations for physical education and physical activity promotion in schools. Prog Cardiovasc Dis. 2015;57(4):368-374. doi: 10.1016/j.pcad.2014.09.010 pmid: 25269062

12.Ruseski JE, Humphreys BR, Hallman K, Wicker P, Breuer C. Sport participation and subjective wellbeing: instrumental variable results from German survey data. J Phys Act Health. 2014;11(2):396-403. doi: 10.1123/jpah.2012-0001 pmid: 23363531

13.Ravasizadeh M, Naghshbandi S. Identifying and Prioritizing the Opportunities and Challenges of Champion School Plan with the AHP Method. Res Educat Sport. 2020;8(18):135-156. doi: 10.22089/res.2019.7018.1612

14. Fitzgerald H. Sport is not for all: The transformative (im) possibilities of sport for young disabled people. Sport and physical activity across the lifespan London: Palgrave Macmillan; 2018.

15. Rasekh N, Sajjadi SA, Razavi SMH, Dostyee M. Structural analysis of educational exercise in Iran. Res Sport Educat. 2018;6(14):17-44.

16. Bocarro JN, Kanters MA, Cerin E, Floyd MF, Casper JM, Suau LJ, et al. School sport policy and schoolbased physical activity environments and their association with observed physical activity in middle school children. Health Place. 2012;18(1):31-38. doi: 10.1016/j.healthplace.2011.08.007 pmid: 21900034

17.Pot N, Schenk N, van Hilvoorde I. School sports and identity formation: socialisation or selection? Eur J Sport Sci. 2014;14(5):484-491. doi: 10.1080/17461391.2013.873483 pmid: 24382207

18. Ghasemi H, Tojari F, Borojerdi M, Emami H, Amiri M. Content analysis of the views of heads of the physical education organization about the components of sport from 1357 to 1388. Sport Manage. 2012(13):137-152.

19. Khouzani MN, Aroufzad S, Nadi MA. Identifying the underlying factors affecting the development of participation of student sport in Iran. J Human Sport Exercise. 2020;15(2):S379-S392. doi: 10.14198/jhse.2020.15.Proc2.29 
20. Rahim M. Study Educational Exercise of the comprehensive sports development system of the country based on the SWOT model. Master's Thesis, Allameh Tabatabai University of Tehran.2011.

21.Naseh M, Khabiri M, Jalali Farahani M, Sajjadi SN. Examining the theoretical foundations of educational-pedagogical exercise and extracting the effective and influenced factors of. 2018.

22. Rastogi P, Sharma K. A Review of physical education status in school education system. India J Appl Res. 2017;7(7):79-96.

23. Samei S, Tojari F, Nik Aeen Z. Analyzing the Trend of Managerial Changes in Iranian Student Physical Education and Sport (2018-1978). Res Educat Sport. 2020;8(19):179-200. doi: 10.22089/res.2019.7232.1645

24.Zolghadri P, Kian M, Aliasgari M, Elahi AR. Pathology of the Implementation of Physical Education and Health Curriculum in First Level Secondary School, based on Aker Model. Res Educat Sport. 2019;7(17):229-252. doi: 10.22089/RES.2019.5941.1475

25. Saatchian V, Keshtidar M, Ranaei M, Azizi B. Explaining the Factors Affecting the Success of the Intramural Sports Olympiad. Res Educat Sport. 2019;7(16):39-60. doi: 10.22089/RES.2018.5036.1384

26. Mirzaei Kalar A, Hemmatinezhad MA, Ramezaninezhad R. Designing the Model of Student Sport Development in Iran. Res Educat Sport. 2020;8(18):41-62. doi: 10.22089/res.2019.6508.1557

27. Mirzazadeh Z, Shajie K. Designinig and Development Strategic Plan of University Sport (Case Study: Physical Education Office of Ferdowsi University). Res Educat Sport. 2016;5(12):61-78. doi: 10.22089/res.2017.939

28. Mull RF, Forrester SA, Barnes ML. Recreational sport Programming". Urbana, Sagamore Publishing LLC, (5th ed.)2005.

29. Shilbury S, Sotiriadou K, Green C. Sport development systems, policies and pathways, an introduction to the special issue". Sport Manage Rev. 2008;11:217-223. doi: 10.1016/S1441-3523(08)70110-4

30. Keshavarz L, Farahani A, Rezaee Soufi M, Hesami L. Interaction Analysis of Educational Sports Development Strategies. Case Study Kurdistan Province. 2020;7(27):67-79.

31. Shabani A. Iran sport structured environment analysis based on hierarchical model sport. (Doctoral dissertation). Payam Noor University (PNU), Tehran.2015.

32. Tsangaridou N. Early childhood teachers' views about teaching physical education: challenges and recommendations. Physic Educat Sport Pedag. 2017;22(3):283-300. doi: 10.1080/17408989.2016.1192593

33. Vafaie Moghaddam A, Dosti M, Fakhri F, Jafari M. Investigating Barriers to School Sport Development in Mazandaran Province. J Sport Manage Motor Behav. 2019;14(28):167-182. doi: 10.22080 / jsmb.2018.8523.2159

34.Pilevar Mokhar E, Alai M, Peyman ZH. Identifying Internal and External Opportunities and Challenges of Student Sport in Khorasan Razavi Province. Educat Stud. 2014;3(9):95-112.

35. Abdi Moghadam S, Ramazani Nejad R, Pourseltani H. Comparison of the Physical Education Course Educational Position from the Viewpoints of Principals, Teachers, Parents, and High School Students. Physiol Manage Res Sport. 2018;10(1):129-143.

36. Vahdani M. Achieving a healthy and active lifestyle by developing physical literacy. $J$ Sport Value. 2016;2(175):21-22.

37. Mostashiri E, Mostashiri N, Mostashiri SM, Bahar S. Investigating Motivational System for Attracting Students and Developing Their Sports Activities (Case Study: Semnan Students). Growth Psychol. 2017;6(4):217-240.

38. Ghanbari H, Shetabbushehri N, Shafiniya P, Mehralizadeh Y. Pathology of Physical Education and School Sports by Applying Three Dimensional Model. Res Educat Sport. 2019;6(15):149-160. doi: 10.22089/RES.2017.4786.1359

39. Mohammadi V. Barriers and impellent the male and female high school students in Ardabil in sports. (Unpublished master's thesis). Payam Noor University, Tehran.2012.

40. Soltani Moghadam N. Study of the teaching of physical education course in elementary schools in South Khorasan province. (Unpublished master's thesis). Birjand University, Birjand.2014.

41.Hashemi S. Identify barriers to the development of basic sports schools of Tehran. (Unpublished master's thesis). Islamic Azad University of Tehran, Tehran.2015. 
42. Valadi S, Hamidi M. Studying the Level of Physical Literacy of Students Aged 8 to 12 Years. (Persian). Res Educat Sport. 2020;8(20):205-226. doi: 10.22089/res.2018.5090.1388

43. Malihi M, Ali Asgari M, Agaee N, Javadipour M. Content analysis of preschool books in terms of attention to physical activity. Quarter J Educat. 2018;142:43-26.

44. sadatmand Z, Liaqtdar MJ, Sadeghian Z. Needs assessment of preschool curriculum under the supervision of education from the perspective of managers and educators in Isfahan. J Curriculum Res. 2012;9(8):132-145.

45.Jahandideh MA, Lotfi Gh. Collaborative Learning, a New Approach to Physical Education Training. Develop Physic Educat Educat. 2016;16(3):12-15.

46. Shahbazi M, Shabani Moghadam S, Saffari M. Public Sports (Necessity, Obstacles and Strategies). Quarter J Parliament Strategy. 2013;20(76):97-70.

47. Ghanbari Firouzabad AR, Amani A, Riehani M, Sardroodian M. Designing a Strategic Model for Student Sport Development. Res Educat Sport. 2020;8(20):179-204. doi: 10.22089/res.2020.7838.1732

48. Welty Peachey J, Cohen A, Musser A. A phone call changed my life': Exploring the motivations of sport for development and peace scholars. J Sport Develop. 2016.

49. Razavi SMH, Shabani B, Sajjadi GR, Seyyed A. Analysis of factors influencing the quality of physical education in secondary schools from the point of view of sports teachers. Res Sport Manage Motor Behav. 2009;7(14):103-112.

50. Teodor C, Caludiu M. The role of motivation in education through sport. Procedia Soc Behav Sci. 2013;83:1054-1058. doi: 10.1016/j.sbspro.2013.06.196

51.Mozaferi SAA, Elahi A. Development comprehensive system of champion sport in Islamic Republic of Iran. Res Project Sport Sci Res Institute Iran Ministry Sci Res Technol. 2009. 